\title{
NOTES
}

\section{IN THE MATTER OF COUNTERCLAIMS IN BANKRUPTCY: SUMMARY PROCEDURE AND THE JURISDICTION OF THE BANKRUPTCY REFEREE*}

\begin{abstract}
CREDITORS of a bankrupt's estate who seek to participate in the distribution of its assets must submit their claims to proof in the bankruptcy court. ${ }^{1} \mathrm{~A}$ referee, sitting as a court of bankruptcy, ${ }^{2}$ has jurisdiction to adjudicate the validity of these claims by "summary" procedures, without right of jury trial. ${ }^{3}$ Section 68 of the Bankruptcy Act provides that "mutual debts or credits" between the creditor and trustee should be offset against each other, by setoff or counterclaim, and only the net balance allowed or paid. ${ }^{4}$ The referee has jurisdiction to implement this section by determining the validity of any defense or setoff the trustee has asserted against a claim filed in the bankruptcy
\end{abstract}

*Dwyer v. Franklin, 227 F.2d 152 (7th Cir. 1955) (In the Matter of Majestic Radio and Television Corp.), petition for cert. filed, 24 U.S.L. WeEK 3214 (U.S. Feb. 14, 1956) (No. 671).

1. When a petition in bankruptcy is filed, the bankruptcy court assumes jurisdiction of all property which the debtor possesses, or to which he has title, as of that time. Thompson v. Magnolia Petroleum Co., 309 U.S. 478 (1940); 30 Stat. 565 (1898), as amended, 11 U.S.C. $\$ 110(a)$ (1952). Under $\$ \$ 57 c$, $n$, of the Bankruptcy Act, general creditors who have claims against the bankrupt estate must file their claims with the bankruptcy court before the claims can be allowed. 30 STAT. 560 (1898), as amended, 11 U.S.C. $\$ \$ 93(\mathrm{c})$, (n) (1952). See Pepper v. Litton, 308 U.S. 295 (1939); United States Fidelity and Guaranty Co. v. Bray, 225 U.S. 205 (1912).

2. " 'Court' shall mean the judge or the referee of the court of bankruptcy in which the proceedings are pending." 30 STAT. 544 (1898), as amended, 11 U.S.C. $\$ 1(9)$ (1952). The referee may now exercise almost all the powers of a trial judge. See note 39 infra and accompanying text. The terms "bankruptcy court" or "court of bankruptcy" are hereinafter used to refer to the referee in bankruptcy rather than the judge of a district court, unless otherwise indicated. See MacLachlan, Protection and Collection of Property of Bankrupt Estates, 39 MinN. L. Rev. 626, 634 n.26 (1955).

3. Section 2a (2) of the Bankruptcy Act, 30 STAT. 545 (1898), as amended, 11 U.S.C. $\$ 11$ (a) (2) (1952), gives the bankruptcy court jurisdiction to allow or disallow all claims against the bankrupt's estate. As in all proceedings in the bankruptcy court, summary procedures are used. See MacDonald v. Plymouth Trust Co., 286 U.S. 263 (1932); 2 Coltrer, Bankruptcy If 23.02 (14th ed., Moore \& Oglebay 1940) (hereinafter cited as ColLIER). Summary proceedings are begun by petition, and are generally somewhat less formal and lengthy than the "plenary" procedures of a regular civil action, but there is no substantial difference in the procedures used as such. Ibid.; see 3 id. $\pi$ 57.18; MacLachlan, supra note 2, at 634-40. More important than the procedural differences is the fact that in summary adjudications (1) a referee presides instead of a judge, see note 2 supra, and (2) the constitutional right to jury trial does not obtain, see notes $52-57$ infra and accompanying text.

4. "Setoffs and Counterclaims.-a. In all cases of mutual debts or mutual credits between the estate of a bankrupt and a creditor the account shall be stated and one debt 
court. 5 When, however, the trustee asserts a counterclaim for an amount in excess of the original claim, there has been considerable doubt whether the referee has jurisdiction to determine the validity of the counterclaim and to award an affirmative judgment to the trustee. ${ }^{6}$ For asserting a counterclaim is more like initiating an original suit than is asserting a setoff. And if the creditor had not filed his claim in the bankruptcy court, and had not otherwise "consented" to summary adjudication, section 23 of the Bankruptcy Act would have permitted the trustee to initiate his claim against the creditor only by a regular civil action in a court of general jurisdiction in which the bankrupt could have sued. ${ }^{7}$

The cases recently have tended, although not universally, to uphold the counterclaim jurisdiction of the bankruptcy court on the theory that the counterclaim defendant had impliedly consented to it by filing his claim. ${ }^{8}$ The older cases held jurisdiction lacking in the absence of actual consent. 9

shall be set off against the other, and the balance only shall be allowed or paid." 30 Star. 565 (1898), 11 U.S.C. \& 108 (a) (1952).

A setoff differs from a counterclaim only in that the latter seeks an award in excess of the original claim against which it is filed, whereas the former seeks only to offset the claim in part. Either may be related or unrelated to the subject matter of the original claim. This is the terminology suggested in 4 Collier f 68.03 . The terms "counterclaims" and "setoffs" also include claims to recover preferential or fraudulent transfers voidable under the terms of $\$ \$ 60,67$ and 70 of the Bankruptcy Act. The trustee may not seek to recover preferential or fraudulent transfers under $\S 68$ because the transfer is not a "mutual" debt within the meaning of $\$ 68$. See Mechanics' and Metals Nat'1 Bank v. Ernst, 231 U.S. 60 (1913); United States v. Roth, 164 F.2d 575, 578 (2d Cir. 1948). However, $\$ 57 \mathrm{~g}$ of the Bankruptcy Act provides that claims filed by a creditor who has received a transfer voidable under $\$ \$ 60,67$ or 70 of the Act shall not be allowed against the estate unless the transfer is first surrendered by the creditor. See, generally, 3 Collier $\{57.19 ; 4 i d$. $\{68.08$. Thus the problem whether the referee may, for purposes of $\$ 57 \mathrm{~g}$, determine that an allegedly voidable preference or transfer may in fact be avoided is analogous to the problem whether he may determine, for the purposes of $\S 68 \mathrm{a}$, that an alleged debt is in fact validly owing to the trustee. The problems being similar, it is believed that conclusions reached in the following analysis may be based upon, and will apply to, cases arising under $\$ 57 \mathrm{~g}$ as well as $\$ 68$ a.

5. See note 12 infra and accompanying text.

6. See cases cited note 11 infra. See, generally, 4 Corlrer $\{68.20$ (collecting citations); MacLachlan, supra note 2, at 642-44; Nadler, Sunmmary Jurisdiction to Render Affirmative Judgment on Counterclains, Sctoffs and Reclanations, 29 REF. J. 39 (1955).

7. "Suits by the ... trustee shall be brought or prosecuted only in the courts where the bankrupt might have brought or prosecuted them if proceedings under this title had not been instituted, unless by consent of the defendant. ..." 30 Stat. 552 (1898), as amended, 11 U.S.C. $\$ 46$ (b) (1952). For detailed analysis of when $\S 23$ applies, see note 23 infra; notes $26-31$ infra and accompanying text.

8. See, c.g., Inter-State Nat'l Bank v. Luther, 221 F.2d 382, 389 (10th Cir. 1955), cert. dismissed, 350 U.S. 944 (1956): "[T]he jurisdiction of the court is based upon implied consent by invocation and is sustainable upon ... equitable jurisdiction to render full and complete relief as between petitioning parties to the court." See also cases cited note 11 infra.

9. E.g., Thallhimer, Inc. v. Florance, 58 F.2d 23 (4th Cir. 1932); Triangle Elec. Co. v. Foutch, 40 F.2d 353, 357 (Sth Cir. 1930) (dictum); Metz v. Knobel, 21 F.2d 317 (2d Cir. 1927). 
In 1935; however, the Supreme Court determined that filing a claim in an equity receivership proceeding should be deemed consent by "invocation" to the receivership court's jurisdiction over a permissive counterclaim. ${ }^{10}$ The majority of circuits thereafter began to find consent more readily in bankruptcy cases. ${ }^{11}$ They buttressed the finding with a statutory argument: since the referee could summarily adjudicate the validity of a defense or setoff asserted by the trustee, ${ }^{12}$ it was assumed that he also had jurisdiction to determine the merits of a counterclaim; for the counterclaim, although it sought an affirmative award, also sought in part to offset the claim of the creditor. ${ }^{13}$

10. Alexander v. Hillman, 296 U.S. 222 (1935). The Supreme Court held that invoking the jurisdiction of the receivership tribunal by filing a claim with it thercby conferred in personam jurisdiction upon the receivership court, enabling it to render an affirmative judgment on a permissive counterclaim. Id. at 241-42. Subject matter jurisdiction was not in issue. Id. at 238 . The decision seemed based primarily upon the desirability of the speed and economy with which cases could be considered and adjudicated by the referee in the receivership court. See $i d$. at 242-43.

Hillman seems in rather sharp conflict with the Court's earlier decision in Daniel v. Guaranty Trust Co., 285 U.S. 154 (1932). In the Danicl case the Court held that the trustee could not assert a permissive counterclaim against a reclamation petitioner in the bankruptcy court. The Court stated that Equity Rule 30 (permitting the procedural device of permissive counterclaims in equity proceedings) should not be applied to bankruptcy: "We cannot conclude that the demand for speedy administration of bankrupt estates is enough to justify such a radical departure from ordinary procedure." Id. at 162 . The legal rationale of the Daniel case is now outdated, since FED. R. Civ. P. 13 makes the use of permissive counterclaims an accepted procedure; rule 13 has been made applicable to bankruptcy proceedings by General Order 37, 305 U.S. 681, 698 (1939). Moreover, the policy subsequently adopted in the Hillman case is applicable to bankruptcy as well as to receivership.

11. Conway v. Union Bank, 204 F.2d 603 (2d Cir. 1953) (chapter X of the Bankruptcy Act), cert. deferred sub nom. Silesian Holding Co. v. Union Bank, 350 U.S. 858 (1955) ; In re Solar Mfg. Corp., 200 F.2d 327 (3d Cir. 1952) (chapter X), cert. denicd sub nom. Marine Midland Trust Co. v. MeGirl, 345 U.S. 940 (1953) ; Florance v. Kresge, 93 F.2d 784 (4th Cir. 1938) ; Floro Realty \& Inv. Co. v. Steem Elec. Corp., 128 F.2d 33S (8th Cir. 1942) (reclamation) (Chapter X) ; Bank of California, Nat'l Ass'n v. McBride, 132 F.2d 769 (9th Cir. 1943) ; Inter-State Nat'l Bank v. Luther, 221 F.2d 382 (10th Cir. 1955), cert. dismissed, 350 U.S. 944 (1956). Contra, B. F. Avery \& Sons Co. v. Davis, 192 F.2d 255 (5th Cir. 1951), cert. denied, 342 U.S. 949 (1952) ; Harris Trust \& Sav. Bank v. Keig, 98 F.2d 952 (7th Cir. 1938), cert. denied, 305 U.S. 658 (1939); Solomon v. Allied Bldg. Credits, Inc., 209 F.2d 828 (8th. Cir. 1954) (semble) ; cf. Fitch v. Richardson, 147 Fed. 197 (1st Cir. 1906). Recent district court cases contra; In re Houston Seed Co., 122 F. Supp. 340 (N.D. Ala. 1954); In re C. A. Goldsmith Co., 122 F. Supp. 191 (D.N.J. 1954) (reclamation); In re Tommie's Dine \& Dance, 102 F. Supp. 627 (N.D. Tex. 1952).

12. See Gardner v. New Jersey, 329 U.S. 565,573 (1947) ( $\$ 77$ of the Bankruptcy Act); Triangle Elec. Co. v. Foutch, 40 F.2d 353, 356 (8th Cir. 1930) (dictum); In re Patterson-MacDonald Shipbuilding Co., 284 Fed. 281 (W.D. Wash. 1922), aff'd on other grounds, 293 Fed. 192 (9th Cir. 1923); In re. Continental Producing Co., 261 Fed. 627 (S.D. Cal. 1919); MacLachlan, supra note 2, at 642. See, generally, 4 Collier $\llbracket 68.20$, at $787-88$.

13. The bankruptcy court merely adjudicated the trustee's counterclaim, disallowing or deferring payment of the creditor's claim, but making no judgment or other affirmative award pursuant to the determination. See, e.g., Fitch v. Richardson, 147 Fed. 197 (1st 
The bankruptcy court's determination of the validity of the setoff was given the effect of collateral estoppel, foreclosing relitigation of the merits in subsequent proceedings. ${ }^{14}$ Therefore a plenary suit to collect the excess was considered a perfunctory step, and most courts concluded that the creditor had in effect "consented" to the entry of an affirmative order in the bankruptcy court. ${ }^{15}$

The recent case of Dwyer $v$. Franklin ${ }^{10}$ rejected the statutory consent rationale. Franklin filed a claim of $\$ 1,481$ for goods sold to the bankrupt; the trustee asserted a counterclaim of $\$ 442,167$ for an alleged breach of fiduciary duty completely unrelated to the original claim. ${ }^{17}$ The Seventh Circuit stated

Cir. 1906); In re Bowers, 33 F. Supp. 965 (S.D. Calif. 1940). Some early cases indicated that jurisdiction could not be exercised unless the trustee waived his right to the amount by which his counterclaim exceeded the creditor's claim. E.g., Triangle Elec. Co. v. Foutch, supra note 12; In re Patterson-MacDonald Shipbuilding Co., supra note 12; In rc Continental Producing Co., stupra note 12. The more recent decisions, however, generally allowed the trustee to recover the excess by a subsequent suit. E.g., Griffin v. Vought, 175 F.2d 186 (2d Cir. 1949); Johnson v. Wilson, 118 F.2d 557 (9th Cir. 1941); In re Nathan, 98 F. Supp. 686, 691 (S.D. Cal. 1951) (dictum). But see B. F. Avery \& Sons Co. v. Davis, 192 F.2d 255 (5th Cir. 1951), cert. denied, 342 U.S. 949 (1952), where the Fifth Circuit applied $\$ 23$ of the Bankruptcy Act to prevent the bankruptcy court from even passing on the validity of the trustee's counterclaim because its determination would have been binding as collateral estoppel. See note 14 infra. The court directed that the claim should be held in abeyance pending a plenary suit by the trustee to recover the alleged preference upon which the counterclaim was based.

14. Schwartz v. Levine \& Malin, Inc., 111 F.2d 81 (2d Cir. 1940); Breit v. Moore, 220 Fed. 97 (9th Cir. 1915) ; B. F. Avery \& Sons Co. v. Davis, supra note 13; MacLachlan, supra note 2 , at $6+2$. There is some question whether the bankruptcy court has jurisdiction to make a determination as to the anount due to the estate; or, if the determination is made, whether it also would operate as collateral estoppel. Most decisions have considered such findings as to the amount conclusive. E.g., Griffin v. Vought, supra note 13; Johnson v. Wilson, supra note 13; Schwartz v. Levine \& Malin, Inc., supra. But see Feiring v. Gano, 114 Colo. 567, 168 P.2d 901 (1946). For extensive discussion, see Gee, $A$ Persistant Conflict Revived Over Collatcral Attack Upon Disallowance of a Clain by a Referee in Bankruptcy, 26 ORE. L. REv. 18S (1947).

15. "The legal result being in substance the same as if actual consent had been given, there exists a rational and solid ground for holding that a creditor, by presenting his claim ... impliedly consents to adjudication by the bankruptcy court in summary proceedings ... of any counterclaim for an affirmative judgment. ..." In re Nathan, $98 \mathrm{~F}$. Supp. 686, 692 (S.D. Cal. 1951) (compulsory counterclaim). See also Inter-State Nat'1 Bank v. Luther, 221 F.2d 382, 389 (10th Cir. 1955), cert. dismissed, 350 U.S. 944 (1956) (permissive counterclaim), quoted note 8 supra; Columbia Foundry Co. v. Lochner, 179 F.2d 630, 633 (4th Cir. 1950) (compulsory counterclaim).

16. 227 F.2d 152 (7th Cir. 1955), petition for cert. filcd, 24 U.S.L. WEEK 3214 (U.S. Feb. 14, 1956)" (No. 671).

17. After Chapter $\mathrm{X}$ reorganization had proven infeasible, the corporation was adjudicated a bankrupt. Transcript of Record, p. 3, Dwyer v. Franklin, 227 F.2d 152 (7th Cir. 1955). While the Chapter $X$ proceedings were pending, Franklin had filed a claim as a supplicr to whom the corporation was indebted on open book account. Id. at 8-10. However, he had also been a director of the corporation, $i d$. at 3 , and during the bankruptcy proceedings the trustee objected to the claim and counterclaimed, alleging that Franklin had participated in the improper authorization of a stock option program, id. at 1s. See also id. at 22-23. 
that filing a claim should be deemed implied consent to summary adjudication of only those counterclaims arising out of the same subject matter as the original claim ${ }^{18}$ without actual consent, ${ }^{19}$ the referee had no jurisdiction even to consider the merits of an unrelated counterclaim. ${ }^{20}$ The court recognized that under section 68 the referee should set off mutual debts and credits, but held that this section merely required him to defer allowance of the creditor's claim until the validity of the trustee's counterclaim could be determined by another court in a regular civil action. ${ }^{21}$ For section 68 establishes a mode of procedure, but does not in itself convey a grant of jurisdiction. ${ }^{22}$ And the Seventh Circuit stated that under section 23 the only courts with jurisdiction to determine claims brought by the trustee against nonconsenting adverse parties are those courts in which the bankrupt could have sued before bankruptcy. ${ }^{23}$

18. "A litigant could hardly claim a recovery on the basis of a certain fact situation without permitting the court to decide all of the legal consequences of that situation." Dwyer v. Franklin, supra note 17 , at 156.

19. As is often the case in counterclaim situations, Franklin (the counterclaim defendant) objected to the bankruptcy court's jurisdiction over either the subject matter of the counterclaim or his person as soon as the counterclaim was asserted. Id. at 154, 156; cf. notes 27,32 infra.

20. Dwyer v. Franklin, 227 F.2d 152, 156 (7th Cir. 1955). Cf. B. F. Avery \& Sons Co. v. Davis, 192 F.2d 225 (5th Cir. 1951), discussed in note 13 supra. Strangely enough, the court did not cite the Davis case. The reason may have been that Davis' counterclaim involved a preference, a situation which the Seventh Circuit may have considered distinguishable. See note 23 infra.

21. Dwyer v. Franklin, supra note 20, at 156-57. The court, wholly on the authority of 1 Axr. JUR., Accounts and Accounting $\$ 16$, at 272 (1939), discussing a different matter, concluded that the mutual debts referred to in $\$ 6 \$ a$, see note 4 stepra, "could not refer to an unliquidated claim for damages...." And by "liquidated" the court apparently meant reduced to judgment. But see notes 43-44 infra and accompanying text.

22. Dwyer v. Franklin, 227 F.2d 152, 156-57 (7th Cir. 1955).

23. Id. at 155 . See note 7 supra and accompanying text.

It is possible that the court did not intend its decision to apply to counterclaims involving $\$ \$ 6$ (preferences), 67 (fraudulent conveyances) or 70 (both) of the Bankruptcy Act. The court distinguished the recent Tenth Circuit case of Inter-State Nat'l Bank v. Luther, 221 F.2d 382 (10th Cir. 1955), cert. dismissed, 350 U.S. 944 (1956) (sustaining summary adjudication of permissive counterclaim based upon allegedly preferential transfer), on the ground that there was an exception in $\$ 23$ created for claims arising under $\$ \$ 60,67$ or 70 . The exception to which the court adverted refers to a proviso in each of these sections which states that "where plenary proceedings are necessary ... any court of bankruptcy shall have ... jurisdiction. ..." See, e.g., $\$ 60 \mathrm{~b}, 30$ Star. 562 (1898), as amended, 11 U.S.C. \$ 96(b) (1952). Thus it seems possible that the court would distinguish a future case involving a counterclaim based upon a transaction covered by one of those sections.

Such a distinction would have some merit. Claims not covered by those sections do not arise with as great frequency in bankruptcy litigation. But cf. note 42 infra. Consequently they are not so much of the fabric of the Act, nor so peculiarly within the expertise of the referee.

Nevertheless, the court's distinction does not withstand analysis. For the exception in $\$ 23$ to which it referred has invariably been construed to deal only with federal jurisdiction; it enables the trustee to sue in a district court without respect to diversity 
The Seventh Circuit's analysis of the Droyer case really assumed the conclusion the court reached. True, section 68 is a procedural directive and not a grant of jurisdiction; in bankruptcy, as elsewhere, a court must have separate grounds of jurisdiction in order to adjudicate an unrelated counterclaim. ${ }^{24}$ And if section 23 applies, the only courts with jurisdiction over permissive counterclaims are those in which the bankrupt could once have sued. ${ }^{25}$ Nevertheless, it appears that the court erred in assuming that section 23 did apply simply because the counterclain defendant was a nonconsenting adverse claimant.: If he had not objected to summary adjudication, section 23 would never apply. ${ }^{27}$ But the absence of consent is only one prerequisite to the applicability of the section. Section 23 by its own terms affects only "suits . . . brought or prosecuted" by the trustee. ${ }^{28}$ It comes into operation only if summary procedures cannot, so that plenary procedures must, be used.29 For

of citizenship. It does not grant summary jurisdiction (i.e., jurisdiction to determine a controversy by summary procedures) to the referee. See Williams v. Austrian, 331 U.S. 642, 650 (1947) ; Weidhorn v. Levy, 253 U.S. 268 (1920) ; Harris Trust \& Savings Bank v. Keig, 98 F.2d 952, 957 (7th Cir. 1938), cert. denied, 305 U.S. 658 (1938); 2 CollieR II 23.15 (collecting added citations); MacLachlan, stpra note 2, at 645. But there already was federal jurisdiction in Dwyer, based on diversity. Transcript of Record, pp. 6-9, Dwyer v. Franklin, supra note 22 . The only question (in Dwyer and Luther) was the scope of the bankruptcy court's summary jurisdiction, as to which the exception in $\S 23$ is entirely irrelevant. Thus, the distinction drawn by the Seventh Circuit seems to be without legal substance; it would therefore not be likely, if the argument were brought to the court's attention by counsel, to provide a valid standard for limiting the Dwoyer decision in either the Seventh Circuit or any other court following the Dwyer rule.

24. Sce Inter-State Nat'l Bank v. Luther, 221 F.2d 382, 390 (10th Cir. 1955); In $r$ Nathan, 98 F. Supp. 686, 689 (S.D. Cal. 1951); 4 Collies If 68.02, at 712. For the ordinary rule outside bankruptcy, established by FED. R. CIv. P. 13, see, generally, 3 Moore, Federal Practice, T 13.19[1] (2d ed. 1948).

25. See note 7 supra and accompanying text.

26. The Seventh Circuit completely identified counterclaims with turnover proceedings; the "adverse claimant" concept grew out of and relates to the bankruptcy court's powcrs over the rights of persons not before it. Except for specific statutory grants here irrelevant, the established rule is that absent actual consent, see note 27 infra, the bankruptcy court may not summarily adjudicate the rights of third parties holding property under an adverse claim of right which is more than "colorable." The adverse claimant is entitled to a plenary suit governed by $\S 23 \mathrm{~b}$. Harrison v. Chamberlin, 271 U.S. 191 (1926) ; Taubel-Scott-Kitzmiller Co. v. Fox, 264 U.S. 426, 438 (1924). See 2 CoLlier I 23.06; MacLachlan, supra note 2 , at 637-38. The court assumed the same rule would apply to a party already before the court. Yet these two situations are by no means identical, so that a different treatment may well be proper.

27. See note 7 supra and accompanying text. Answering the trustee's counterclaim without objecting to the court's jurisdiction constitutes "actual" consent to its jurisdiction. In ro Petroleum Conversion Corp., 99 F. Supp. 899 (D. Del. 1951), aff'd per curriam, 196 F.2d 728 (3d Cir. 1952), cert. denied sub 11Qm. Vaughan v. Petroleum Conversion Corp., 344 U.S. 917 (1953); Harris Bank \& Trust Co. v. Keig, 98 F.2d 952, 959 (7th Cir.), cert. denied, 305 U.S. 658 (1938) ; cf. 66 STAT. 420 (1952), 11 U.S.C. \$11(a) (7) ; Nadler, supra note 6 , at 40 .

28. See note 7 supra.

29. See note 30 infra.

Section $2 \mathrm{a}(7)$ of the Bankruptcy Act, quoted in note 33 infra, grants the bankruptcy 
section 23 limits the jurisdiction of the district, but not the bankruptcy courts. ${ }^{30}$

The real question in the Dwyer case is not whether the creditor "consented," but whether permissive counterclaims asserted against a clainant in a bankruptcy court should be determined by summary or plenary procedures. In statutory terms, the question is whether an unrelated counterclaim, responsively asserted by the trustee in a proceeding he has not initiated, is sufficiently like a "suit ... brought or prosecuted" by him that it should fall within the operation of section 23. ${ }^{31}$ The terms of the Bankruptcy Act do not provide an answer to these questions.

If section 23 need not be applied, the referee would have the jurisdiction over person and subject matter necessary to award judgment on the counterclaim-with or without the creditor's consent. ${ }^{32}$ The bankruptcy court is in-

court jurisdiction over controversies amenable to summary adjudication. But Congress did not attempt to establish a formula by which to determine when a controversy should come under "summary" or "plenary" procedures; it left that question to the courts. See Taubel-Scott-Kitzmiller Co. v. Fox, 264 U.S. 426, 431 n.8 (1924); of. 2 CoLLIER I 23.02. The answer has been largely circular: a plenary suit is necessary if the bankruptcy court does not have "summary jurisdiction." Professor MacLachlan states that the bankruptcy court's summary jurisdiction is limited by "concepts of tradition, of due process, and of common sense." MacLachlan, supra note 2, at 644 .

The general rule established for turnover proceedings is that summary jurisdiction exists only when the adverse party does not assert a more-than-colorable claim of right. See notes 7,26 supra. But this rule is wholly oriented towards a situation in which the adverse claimant is not already in the bankruptcy court. And if for other reasons, see notes 32-37 infra and accompanying text, it appeared that $\$ 2 \mathrm{a}(7)$ would grant summary jurisdiction to the court without possession of property held under an adverse claim of right, then a plenary suit would not be necessary and $\S 23$ would not apply.

30. 2 CoLIIER $\int 23.03$ (collecting citations); MacLachlan, supra note 2 , at $644-45$ ("Section 23 governs the plenary jurisdiction, and Section ... [2a(7)] the summary, and the relation between them [is] purely complementary. ..."); Moore \& Tone, Proposed Bankruptcy Amendments: Improvement or Retrogression? 57 YALE L.J. 683, 71011 (1948). See also discussion in City of Long Beach v. Metcalf, 103 F.2d 483 (9th Cir.), cert. denied, 308 U.S. 602 (1939). Thus it is misleading to take the view of the Drvycr case that $\$ 23$ "limits" the grant of jurisdiction to the bankruptcy court in $\$ 2 \mathrm{a}(7)$. Section 23 applies only if a plenary suit is necessary-in which case, by definition, $\$ 2 a(7)$ is already inoperative. See note 29 supra. This seems true even though $\S 2 a(7)$, and not $\$ 23$, is the source of the district court's grant of jurisdiction over plenary cases. See Williams v. Austrian, 331 U.S. 642 (1947) (Chapter X).

31. In other contexts a counterclaim has not always been treated as an original suit brought by the (original) defendant. See, e.g., Alexander v. Hillman, 296 U.S. 222, 240 (1935) (counterclaim is not an "original action" for purposes of a venue statute); Sheets v. Shamrock Oil \& Gas Corp., 115 F.2d 8s0, 882-83 (5th. Cir. 1940), aff'd, 313 U.S. 100, 106-107 (1941) (counterclaim defendant is not "defendant" for purposes of removal statute).

32. The fiction of "implied consent" has been used to achieve results which seem sound. See cases cited note 11 supra. But several district courts have bridled at the use of so fictional a standard, and have refused to imply consent when the counterclaim defendant objected to counterclaim jurisdiction as soon as it was asserted. See district court cases cited note 11 supra; cf. note 19 supra. The issues are more clearly brought into focus if the fiction is discarded; and the fiction is not necessary to arrive at the desired 
vested with subject matter jurisdiction at law and in equity to determine all controversies related to the collection and disposition of the bankrupt estate. ${ }^{33}$ This jurisdiction may be exercised when the bankruptcy court has jurisdiction over the thing in controversy. ${ }^{34}$ It would seem equally operative if there were jurisdiction over the person of the claimant rather than the thing which he is claiming. ${ }^{3 J}$ And in the counterclaim situation, unlike turnover proceedings initiated by the trustee, the bankruptcy court would have jurisdiction over the person of the adverse claimant. ${ }^{36}$ Absent special considerations, every court has personal jurisdiction over any person appearing before it. ${ }^{37}$

result. For the question is not so much whether there was consent as whether the counterclaim defendant is precluded from objecting to the assertion of statutory jurisdiction. See notes 33-38 infra and accompanying text.

33. Section $2 \mathrm{a}(7)$ of the Bankruptcy Act provides: "The [judge or the referee of the court of bankruptcy in which the proceedings are pending is] . . hereby invested ... with such jurisdiction at law and in equity as will enable them to . . (7) Cause the cstates of bankrupts to be collected . . . and distributed, and determine controversies in relation thereto," unless limited by $\$ 23$. 30 STAT. $545-46$ (1899), as amended, 11 U.S.C. \$ 11 (a) (7) (1952).

Section 23 does not really limit the extent of the bankruptcy court's jurisdiction over subject matter. Rather, it provides a directive as to which courts may hear "suits" "brought or prosecuted" by the trustee. By definition, the bankruptcy court did not have jurisdiction to hear these suits in the first place. See notes 30-31 supra and accompanying text. But the reason the bankruptcy court could not adjudicate these disputes is not lack of stbject matter jurisdiction: it is lack of jurisdiction over the person or thing involved. This seems apparent because $\$ 2 a(7)$ grants co-extensive subject matter jurisdiction to both the district court and the bankruptcy court. Williams v. Austrian, 331 U.S. 642 (1947).

34. The numerous authorities are collected in 2 CoLLIER f 23.05-23.08.

35. Generally, jurisdiction over the thing is not necessary if a court has jurisdiction over the person claiming or possessing the thing. See, e.g., Phelps v. McDonald, 99 U.S. 298, 308 (1878) ; Philadelphia Co. v. Stimson, 223 U.S. 605, 623 (1912); Detroit Trust Co. v. Campbell River Timber Co., 98 F.2d 389, 392 (9th Cir. 1938) ( $\$ 77 \mathrm{~B}$ of the Eankruptcy Act); Restatement, Jungarents 5-7 (1942); cf. Pennoyer v. Neff, 95 U.S. 714 (1877).

Nor is there anything inherent in the nature of bankruptcy proceedings that would limit the courts to in rem jurisdiction. See Taubel-Scott-Kitzmiller Co. v. Fox, 264 U.S. $426,430-31$ (1924). When property is in the court's possession, the court may issue an order to the claimant to show cause why his claim to it should not be avoided; if he does not appear, his rights may be detcrmined without his presence. See generally 2 CoLlier If 23.05[2]. If the party already is before the court, there would seem to be no reason why the court could not determine his rights in regard to all claims properly within its subject matter jurisdiction. See Detroit Trust Co. v. Campbell River Timber Co., supra at $392(\S 77 \mathrm{~B})$.

36. Ey filing a claim or initiating a suit a party is within the court's in personan jurisdiction for all matters procedurally authorized and within the court's subject matter jurisdiction. Sce Adam v. Saenger, 303 U.S. 59 (1938); Alexander v. Hillman, 296 U.S. 222 (1935) (equity receivership); Young v. McNeal-Edwards $\mathrm{Co}_{2} 283$ U.S. 398, 400 (1931); Conway v. Union Bank, 204 F.2d 603 (2d Cir. 1953), cert. deferred sub nom. Silesian Holding Co. v. Union Bank, 350 U.S. 858 (1955).

A "consent" rationale is unnecessary; the rule is better stated positively. There is no reason to treat filing a claim as merely a "special appearance" which the claimant may limit to suit his purposes. To do so would be contrary to the policy of the Bankruptcy 
There are compelling arguments in favor of considering section 23 inapplicable to the counterclaim situation in order to sustain the summary jurisdiction of the bankruptcy court. The underlying objection to summary adjudication of counterclaims apparently is, although never explicitly recognized in the cases, a general belief among creditors that referees are collection conscious. ${ }^{38}$ But it is contrary to the policy of the Bankruptcy Act to presume that referees are unduly favorable to the estate: the Act has continually attempted to promote the referee, sitting as a court of bankruptcy, to the full power, prestige and responsibility of a trial judge. ${ }^{39}$ The expanded role of the referee serves

Act. See notes 38-44 infra and accompanying text. Moreover, special appearances are generally confined to appearances to challenge jurisdiction. RESTATEMENT, JUDGMIENTS $\$$ 20 (1942). If filing a claim is a general appearance, however, the court then has jurisdiction over the claimant for all purposes to which its subject matter jurisdiction extends; and if permissive counterclaims are procedurally permissible-they are in bankruptcy, see note 4 supra and accompanying text; note 10 supra-the court has jurisdiction to award an affirmative judgment against the original claimant. See cases cited supra; RestuTEMENT, JUDGMENTS $\$ 21$, comment $c(194 \hat{z}) ; c f . i d . \$ \$ 19,20$.

37. See note 36 stpra and accompanying text.

"Special" considerations may exist in two situations. (1) If the trustee has a turnover order issued against a third party as to property in the actual or constructive possession of the court, that party ought to be able to prevent the trustee from asserting another claim, concerning property not in the court's possession, after the third party has come in to defend the turnover order. Cf. Ex Parte Indiana Transp. Co., 244 U.S. 456 (1917). This would be consistent with the Bankruptcy Act because the claim subsequently asserted by the trustee would clearly seem to be a "suit" "brought or prosecuted" by him within the meaning of $\$ 23$, and therefore entitled to plenary adjudication without respect to the bankruptcy court's jurisdiction. (2) If the third party, rather than presenting proof of claim, comes to the bankruptcy court to reclaim specified property in the court's actual possession, it might be considered appropriate to permit him to limit his appearance to questions concerning that property. If that conclusion is reached, although it is not here advocated, a special exception could be created for the situation on the theory that his appearance was not as a claimant but as an "owner."

38. See MacLachlan, Protection and Collection of Property of Bankrupt Estates, 39 Mrns. L. REv. 626, 639-40 (1955). This belief seems due in large part on the historical fact that the referee's compensation was based wholly on a percentage of the amount disbursed to creditors as dividends; every claim on which the trustee prevailed was of direct financial benefit to the referee. See S. REP. No. 959, 79th Cong., 2d Sess. 1-3 (1946); Report of the Attorney General's Compitttee on Bankruptcr Aduinistration, ApiIINISTRATION of the Bankruptcy ACT 9497 (1940); Hunt, Stmmary Jurisdiction in Bankruptcy Proceedings, 50 Coxr. L.J. 59 (1945); Statement of Senator Huffman, 92 Cong. Rec. 6386 (1946) ; 2 Collier 40.05-40.09. This system was abolished in 1946, and the referee is now paid an annual salary (up to $\$ 12,500$ ) wholly independent of the amount of money brought into the bankrupt estate. 60 STAT. 326 (1946), as amended, 11 U.S.C. § 68 (1952). See, generally, Chandler, The Outlook Under the New Referec Act, 21 ReF. J. 9 (1946).

39. See, e.g., H.R. Rep. No. 1037, 79th Cong., 1st Sess. 1-2 (1945); Statement of Senator Huffman, 92 Cong. REc. 6386 (1946). Except for lack of power to issue injunctions against courts and punish for contempt, his powers are the same as those of the trial judge. See, generally, 2 CoLLIER ff 38.02. General Order 47, 305 U.S. 702 (1939), dictates that on review the findings of the referee are to be accepted unless "clearly erroneous." To contribute further to his judicial status, the referee has been accorded a 
two valid purposes. By centralizing litigation in a single court of bankruptcy, with an up-to-date calendar, the Act promotes more expeditious and economical disposition of the bankrupt estate, thus allowing a more generous dividend to all general creditors. ${ }^{40}$ Furthermore, by presenting most of the controversies arising from the bankrupt's insolvency before one trier of fact, the latter is able to acquire a greater expertise in dealing with the complex factual and legal issues which arise from the insolvency. ${ }^{41}$ Indeed, it has been suggested that it is often this expertise, and not a predisposition to favor trustees, that makes creditors wary of the bankruptcy court. ${ }^{42}$

Furthermore, section 68, although not a grant of jurisdiction, constitutes a recognition of policies which strongly indicate that summary jurisdiction over counterclaims ought to be sustained. While section 68 does not expressly state which court is to determine the validity of a setoff or counterclaim, it is oriented towards eliminating multiple litigation in different courts. ${ }^{43}$ To promote this

greater degree of tenure (formerly two, now six years). See 60 STAT. 324 (1946), as amended, 11 U.S.C. $\$ 62$ (1952).

If in a given case the referee's findings are unduly favorable to the trustee, judicial review by the district court is always available, even on interlocutory decisions, to correct shown errors or prejudices. See $\$ 39 \mathrm{c} ; 2$ CoLLIER $\{39.21$. Moreover, an inarticulate presumtption of prejudice is in conflict with the congressional intent to create a judicial status for the referce in order to facilitate the administration and distribution of the bankrupt estate. See Report of the Attorney General's Comsurtee, op. cit. supra, note 38, at 94-97.

40. The number of referees available can easily be increased to meet changes in work load. See Annual Report of the Director of the Adninistrative Office of the United States Courts 61 (1949); S. Rep. No. 959, 79th Cong., 2d Sess. 4 (1946). Therefore summary litigation could be more speedily begun than if the trustee were forced to resort to crowded courts of general jurisdiction. See 2 CoLLIER II 23.02[2]; Elpern, The McLaughlin Bill to Establish a System of Full-Time, Salaried Referees in Bankruptcy, 29 VA. L. Rev. 168, 170 (1942). Moreover, the estate would also be saved the added expense of costs and attorney's fees incident to enforcing claims in plenary proceedings in remote forums. Cf. Chandler, supra note 38; Hunt, supra note 38; United States Fidelity \& Guaranty Co. v. Bray, 225 U.S. 205, 218 (1912).

41. Furthermore, uniform treatment of all the bankrupt's creditors should result from adjudication of as many claims as possible by a single judge. And to the extent that certain types of issues are frequently raised in bankruptcy proceedings, the referee develops an expertise in regard to the "bankruptcy specialties." See note 42 infra. An analogy is suggested to the expertise of administrative agencies.

42. Gende1, Jurisdiction of a Referee in Bankruptcy to Render Affirmative Judgment on a Countcrclaim in Favor of a Trustee, 26 So. CaLrF. L. REv. 167, 172-73 (1953); cf. Utley, Summary Iurisdiction, 16 REF. J. 38, 39-40 (1941). Claims of breached fiduciary duty, such as those raised in the Dwyer case, see note 17 supra and accompanying text, while not "bankruptcy specialities" as fully as preferences and fraudulent conveyances, are quite frequently raised by trustees in proceedings concerning corporate debtors. Fiduciary liability was involved not only in Dwyer, but in, e.g., Williams v. Austrian, 331 U.S. 642 (1947) ; Alexander v. Hillman, 296 U.S. 222 (1935) ; In re Solar Mfg. Corp., 200 F.2d 327 (3d Cir. 1952) ; Harris Trust \& Sav. Bank v. Keig, 98 F.2d 952 (7th Cir. 1938).

43. The court before which a claim is asserted has the primary duty of determining for itself whether there are "mutual debts or credits" that should be set off against one another. See Cumberland Glass Mfg. Co. v. De Witt, 237 U.S. 447 (1915); In re Rosenbaum Grain Corp., 103 F.2d 656 (7th Cir. 1939) ; In re Nathan, 98 F. Supp. 686, 692 (S.D. Cal. 1951) ; 4 CollIER \6 68.02, at 710. 
policy, counterclaims should be adjudicated by the court in which the original claim was filed. ${ }^{* 4}$ The decision in the Dwyer case would compel the opposite result, and precipitate the very circuity of litigation which section 68 was designed to prevent. Under Dwyer the trustee may set off not "mutual debts or credits" but only judgments.

There are also policies promoted by section 23 , primarily concerning venue and trial by jury, ${ }^{45}$ which should not be ignored. The policies are not always pertinent to the counterclaim situation. When they are, however, they tend to blur the significance of a verbal distinction between commencing a suit and filing a counterclaim. The distinction is further obscured the less related the counterclaim is to the subject matter involved in the original claim, and the greater the excess amount the trustee seeks. Alternative procedures exist, however, by which the policies implicit in section 23 may be fully effectuated without broadly construing that section to oust the bankruptcy court of summary jurisdiction over counterclaims. ${ }^{46}$

Section 23 is essentially a venue provision. ${ }^{47}$ Therefore, it would seem that the filing of a relatively small, liquidated claim in the bankruptcy court-the

44. See note 43 supra.

Similarly, when the trustee initiates a plenary suit outside the bankruptcy court, the defendant should be able to assert any setoff or counterclaim he had against the trustee. This is the general rule. E.g., Wiilcox v. Goess, 92 F.2d 8 (2d Cir. 1937), cort. denicd, 303 U.S. 647 (1938); Norfolk \& W. Ry. v. Graham, 145 Fed. 809 (4th Cir. 1906). But cf. Page v. Rogers, 211 U.S. 575 (1909) (special exception required when unsecured claim resulting from avoidance of transfer necessarily equals amount recovered by trustee); Keppel v. Tiffin Sav. Bank, 197 U.S. 356 (1905) (same).

45. See notes 47-57 infra and accompanying text.

In addition to jury trial and venue, $\$ 23$ embodied a policy against expanding federal jurisdiction. See Justice Frankfurter's dissenting opinion in Williams v. Austrian, 331 U.S. 642,662 (1947). This was partly done with an eye towards the venue problem, id. at 649 (majority), but also to restrict the business of the already-crowded district courts. See Mussman \& Riesenfeld, Jurisdiction in Bankruptcy, 13 Law \& ConteMp. ProB. \&8, 101 (1948). But it has been pointed out that $\$ 23$ is a limitation on the jurisdiction of the federal district courts, not the referee sitting as a court of bankruptcy. See notes 28-30 supra and accompanying text. Permitting the referee to adjudicate counterclaims by the trustee will decrease the workload of the district courts to the extent that claims now litigated in the district court are heard by the referee. Thus the only objection remaining is that the already-crowded state courts might be jealous of the bankruptcy litigation they will be unable to try.

46. When the counterclaim is far greater in amount than the original claim, and the litigation of each would center about different issues and require different evidence, as is true in the Drvyer case, it would be letting the tail wag the dog to deny that the creditor should have substantially the same rights as if the trustee had brought the counterclaim by a plenary action. It should not be forgotten that $\S 68$ is permissive rather than mandatory. Cumberland Glass Mffg. Co. v. De Witt, 237 U.S. 447, 455 (1915) ; Stanolind Oil \& Gas Co. v. Logan, 92 F.2d 28, 32 (5th Cir. 1937), cert. denied, 302 U.S. 763 (1938); 4 COLIIER $\int 68.02$. The court, even if it has jurisdiction, need not adjudicate the counterclaim if it appears inequitable to do so. See notes 47-51 infra and accompanying text.

47. See Chase Nat'l Bank v. Lyford, 147 F.2d 273, 277 (2d Cir. 1945). Section 23 is "jurisdictional" in the sense that it requires plenary suits to be brought in state courts unless the bankrupt could have brought the suit in the district court. See Schumacher v. 
only court in which the claim could be filed ${ }^{48}$ - should not be grounds for compelling the creditor to litigate the merits of a sizable and unrelated counterclaim in the bankruptcy court if that litigation would entail the production of witnesses and evidence not required for proof of the original claim and not conveniently accessible to the bankruptcy court. ${ }^{99}$ Yet the burden should be on the creditor to show such inaccessibility before it is concluded that the bankruptcy court is an inconvenient forum. ${ }^{50}$ And in any event the consequence of an inconvenient venue should not be loss of jurisdiction by the bankruptcy court; transfer of venue to a more convenient bankruptcy court would seem a more appropriate remedy. ${ }^{51}$

Beeler, 293 U.S. 367, 374 (1934). But congressional intent in enacting $\$ 23$ was to avoid the inconvenience to witnesses and litigants that resulted (in 1898) from the geographical inaccessibility of district courts in many states. Ibid.; see Williams v. Austrian, 331 U.S. $642,649 \mathrm{n} .15$ and legislative history there cited.

48. See note 1 supra and accompanying text.

Venue objections cannot be made to a counterclaim in a regular civil action. General Elec. Co. v. Marvel Rare Metals Co., 287 U.S. 430 (1932). But since the creditor in bankruptcy had to file his claim in the bankruptcy court, if at all, the general rule would seem subject to modification. But cf. Alexander v. Hillman, 296 U.S. 222 (1935) (no venue objection to counterclaim permitted in equity receivership). General Order 37, 305 U.S. 681 (1939), which applies the Federal Rules of Civil Procedure to bankruptcy, explicitly provides that they shall be applied only to the extent they are consistent with the Bankruptcy Act.

49. In the Dzwyer case, Franklin (the creditor) did not argue that it would be inconvenient for him to produce witnesses or evidence on the breach of fiduciary duty question. He did contend, however, that the bankruptcy court would be an inappropriate forum because it was jurisdictionally unable to bring in co-directors whom he felt were interested partics. Brief for Appellee, p. 51, Dwyer v. Franklin, 227 F.2d 152 (7th Cir. 1955); cf. criterion $A(3)$, note 50 infra.

50. It would seem sound to adopt the criteria established for the determination of inconvenient forum in regular civil proceedings in the federal courts. The burden should be on the person claiming the forum is inconvenient to make a compelling showing that the disadvantages to him outweigh the advantages accruing to the trustee by litigating in the bankruptcy court in which claims must be filed. See Gulf Oil Corp. v. Gilbert, 330 U.S. 501, 50 S (1947). In the Gulf case the Supreme Court suggested an illustrative, although not exhaustive, list of revelant criteria. $A$. The private inconvenience should he weighed in terms of (1) access to proof and evidence, (2) cost of obtaining attendance of witnesses, (3) availability of compulsory process to compel unwilling parties or witnesses to appear, (4) possibility of viewing the premises, and (5) enforceability of judgment if obtained. $B$. The public inconvenience should be weighed in terms of (1) congestion of calendars, (2) burden of jury duty, (3) local interest in local controversies, and (4) desirability of applying local law through the court which generally applies it.

51. Although at common law a suit in a court found to be "non conveniens" had to be dismissed, the Judicial Code has established a preferable solution, transfer to a more conveniently located court. 28 U.S.C. \$ 1404 (a) (1952); see Norwood v. Kirkpatrick, 349 U.S. 29 (1955). This procedure should be used also by the bankruptcy court in the counterclaim situation; if the objection to exercise of its jurisdiction is on grounds of venue, the remedy should be in terms of more appropriate venue. Dismissal or transfer to a district court would go well beyond the venue objection.

Transfer of the cause to another bankruptcy court would seem to be authorized by $\S \S 2 a(19),(20)$ of the Bankruptcy Act. Section $2 a(19)$ allows one bankruptcy court to 
It might also be urged that section 23 should be applied, when the trustee asserts a "legal" counterclaim, in order to assure the creditor of trial by jury..$^{62}$ Historically, the constitutional guarantee of trial by jury has never been applied to the equitable proceedings of the bankruptcy court. ${ }^{53}$ Therefore it might be argued that extension of bankruptcy jurisdiction to this class of counterclaims would abridge the right of trial by jury. ${ }^{54}$ This conclusion is

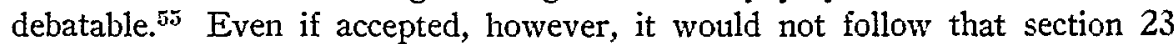
must be invoked to deprive the bankruptcy court of counterclaim jurisdiction. 50 Its jurisdiction recognized for other purposes, the bankruptcy court could be required to transfer the counterclaim to the district court whenever the right to jury was properly claimed; alternatively, it would be possible for the referee specially to impanel a jury in the bankruptcy court when that seemed appro-

transfer a case; $\S 2 \mathrm{a}(20)$ permits another to exercise ancillary jurisdiction when the primary litigation is being conducted in another court of bankruptcy. While these provisions have never been so used, there seems to be no reason why they are not appropriate for the purpose. See Babbitt v. Dutcher, 216 U.S. 102 (1910); cf. In re Lustron Corp., 184 F.2d 789, 797 (7th Cir. 1950), cert. denied sub nom. RFC v. Lustron Corp., 340 U.S. 946 (1951). Alternatively, as a court of equity, the bankruptcy court could allow dismissal only on condition that respondent consent to summary adjudication in a more convenient bankruptcy court.

52. Section $19 \mathrm{c}$ of the Bankruptcy Act provides that "the right to submit to a jury matters in controversy ... shall be determined ... according to the laws of the United States now in force or such as may be hereafter enacted in relation to trials by jury." 30 Stat. 551 (1898), as amended, 11 U.S.C. $\$ 42$ (1952). In the Dwyer case, jury trial was not involved because the trustee's counterclaim was "equitable" in nature. $C f$. note 17 supra and accompanying text.

53. See Barton v. Barbour, 104 U.S. 126 (1881) ; 2 Collier If 19.07; 5 Ḿoore, Federal Practice ๆ 38.30 (2d ed. 1951).

54. These counterclaims have by no means been historically considered within the summary jurisdiction of the bankruptcy court. See notes 9-11 supra and accompanying text. And, when litigated in plenary suits, jury rights obtained as at common law. Therefore, the consequence of now classifying the counterclaim as subject to summary adjudication ordinarily is to restrict the right to have these claims tried to a jury; the summary praceedings traditionally have been without jury.

55. The obvious answer to the argument stated in note 54 supra, is that if such controversies are properly classified as subject to summary adjudication, there is no diminution of a validly subsisting right to trial by jury. Congress could, of course, constitutionally extend the scope of summary jurisdiction in bankruptcy. See Taubel-Scott-Kitzmiller Co. v. Fox, 264 U.S. 426, 430-31 (1924). If the scope already covers counterclains against a defendant before the bankruptcy court, no jury right ever properly existed. Essentially like the argument in note 54, however, this argument begs the question; the conclusion reached would appear to turn upon the relative importance given by the courts to jury trial.

Under the consent rationale the problem of jury rights is easily avoided. Courts upholding summary jurisdiction have held, on the basis of the same consent used to find jurisdiction, that the counterclaim defendant waived his right to jury pro tanto. See, c.g., Inter-State Nat'l Bank v. Luther, 221 F.2d 382, 390 (10th Cir. 1955); In re Nathan, 98 F. Supp. 686, 692 (S.D. Cal. 1951). This rationale is dificult to accept; for if the guarantee of jury trial really exists, it is fictional in the extreme to hold that it was waived when the claimant is not given a reasonable opportunity to claim it. See FED. R. Crv. P. 38; cf. note 19 supra. 
priate. ${ }^{67}$ Either procedure would preserve jury rights without requiring the trustee to initiate new proceedings in a distant forum.

In conclusion, it appears that the competing interests involved in counterclaim situations can best be accommodated by permitting the bankruptcy court to adjudicate permissive counterclaims, with or without the creditor's consent, unless the creditor demonstrates that such adjudication will prejudice his rights. It has been suggested that this conclusion might impede swift liquidation of the bankrupt estate by discouraging creditors from filing relatively small claims when they suspect the trustee may have a more substantial claim against them. ${ }^{58}$ Yet, even conceding this possibility, and the fact that creditors may not easily be shaken from their prejudice against referees, these considerations seem insufficient to justify a failure to implement the congressional policy of increasing the power and status of the referee sitting as a court of bankruptcy.

56. When the trustee's counterclaim involves matters which are usually subject to jury trial it is possible to analogize the situation to the assertion of a legal counterclaim to an equitable suit. In that situation, the counterclaim defendant has a right to jury trial if it is properly claimed. See United States v. National City Bank, \$3 F.2d 236 (2d Cir.), cert. denied, 299 U.S. 563 (1936); Clifton v. Tomb, 21 F.2d 893 (4th Cir. 1927); 3 Mloore, Federal Practice $\int 13.03$ (2d ed. 1948). This is true today, under the Federal Rules of Civil Procedure, not so much on an argument that the federal court lacks equitable jurisdiction of the counterclaim as on the more direct argument that the counterclaim defendant should have his right to jury trial preserved intact. If this analogy is estended to bankruptcy, the claimant met with a "legal" counterclaim in the bankruptcy court will still have his right to jury. Cf. Schoenthal v. Irving Trust Co., 287 U.S. 92 (1932); American Mills Co. v. American Surety Co., 260 U.S. 360 (1922).

57. Section $19 \mathrm{~b}$ of the Bankruptcy Act provides that "if a jury is not in attendance upon the court [defined in $\$ 1(9)$ to include referees], one may be specially summoned for the trial or the case may be postponed." This section would seem to authorize the referee to impanel a jury specially. But sec 2 Collier $\{19.04$, at 227 n.2. Even if it does, however, jury trial would seem to require an experienced trial judge as well as a jury. Transfer to the district court would therefore seem the more appropriate remedy. See Moore \& Tone, Proposed Bankruptcy Amendments: Improvement or Retrogression? 57 YALE L.J. 683, 711 (1948). The jury trial question should not be confused with the venue question, however; if the objection is based on jury rights, the proper district court would seem to be the court which originally referred the matter to the referee.

5S. See Daniel v. Guaranty Trust Co., 285 U.S. 154, 161-62 (1932) ("The risk incident to a general appearance and consent to adjudication of claims of all kinds might easily deter where the right to recover is clear") ; Inter-State Nat'l Bank v. Luther, 221 F.2d 382, 399 (10th Cir. 1955) (dissent).

The extent to which creditors actually would abstain from filing claims is highly speculative. Under $\$ 57 \mathrm{n}$ of the Bankruptcy Act, claims not filed within six months of the general creditors' meeting cannot, ordinarily, be allowed at all. Thus, unless the creditor were quite certain that the trustee had and in fact would assert a sizeable claim against him, and that he would be materially prejudiced by having to litigate the merits before the referee, the creditor would be taking the risk that his claim against the bankrupt would never be realized. 